\title{
PLANNING IN THE NOVEL MENGUKIR LARUT BASED ON THE MANAGEMENT APPROACH
}

\author{
(Perancangan dalam Novel Mengukir Larut Berdasarkan \\ Pendekatan Pengurusan)
}

\author{
Akhmal Hakim Mohamad \\ akhmalhakim_623@yahoo.com \\ Language and Management Lectures, \\ International Islamic University Malaysia.
}

Published on: 3 June 2019

To cite: Ahmad Hakim Mohamad. (2019). Planning in the novel Mengukir larut based on the management approach. Malay Literature, 32(1), 71-92.

\begin{abstract}
This study focuses on a more recent approach in the world of literature in Malaysia known as the Management Approach, which was introduced by Mohamad Mokhtar Hassan in 2013. The novel Mengukir Larut by Amer Hmzah L. Kadir has been selected as the research corpus. The analysis of this study uses the planning principle, which is one of the five principles comprising the Management Approach. This article aims to distinguish and analyse selected events found in Mengukir Larut in order to show the presence of the planning principle. This is a qualitative study using literature review and textual analysis. Based on the detailed observation and analysis towards the occurring events in the selected novel, this study proves a high tendency of the application of the planning principle. The different planning stages such as setting the objective, devising strategies, choosing different alternatives, evaluating various alternatives and choosing one or more ways were the dominant stages in the novel. However, the researcher also found that not all the processes under the planning principle were implemented by the characters in certain events. This study contributes to the world of Malay literature using
\end{abstract}


the Management Approach and proves that the application of literary approaches across different literatures is highly relevant and should be focused upon in future studies.

Keywords: Novel, management approach, planning principle, Mengukir Larut, literary criticism

\begin{abstract}
Abstrak
Makalah ini menekuni sebuah pendekatan baharu dalam dunia kritikan sastera di Malaysia, iaitu Pendekatan Pengurusan. Novel Mengukir Larut karya Amer Hmzah L. Kadir telah dipilih sebagai korpus kajian. Analisis kajian ini menggunakan prinsip perancangan, iaitu merupakan satu daripada lima prinsip yang terkandung dalam Pendekatan Pengurusan seperti yang telah diperkenalkan oleh Mohamad Mokhtar Abu Hassan pada tahun 2013. Makalah ini bertujuan untuk mengenal pasti dan menganalisis peristiwa-peristiwa terpilih yang terdapat dalam korpus kajian yang memperlihatkan kehadiran prinsip perancangan. Kajian ini merupakan kajian kualitatifyang dilaksanakan dengan kaedah kepustakaan dan kaedah analisis teks. Hasil dapatan kajian memperlihatkan kecenderungan yang tinggi bagi menyokong prinsip yang diketengahkan, iaitu prinsip perancangan. Penelitian secara rinci dan analisis terhadap peristiwa yang dilakukan menerusi korpus kajian memperlihatkan penerapan prinsip perancangan. Prinsip perancangan yang diterapkan termasuklah menetapkan objektif, membentuk strategi, pilihan alternatif, penilaian alternatif dan memilih satu atau beberapa cara merupakan peringkat yang dominan dapat dikesan dalam korpus kajian. Pengkaji juga mendapati tidak semua proses dalam prinsip perancangan diaplikasikan oleh watak-watak dalam peristiwa yang terpilih.
\end{abstract}

Kata kunci: Novel, Pendekatan Pengurusan, Prinsip Perancangan, Mengukir Larut, Kritikan Sastera

\title{
INTRODUCTION
}

Amer Hmzah L. Kadir is a local writer who is well known in the arena of writing in Malaysia. He began his writing career with titles such as Kembara Amira (2005), Krisandra \& Cinta Yang Lara (2007), Kala Yuda (2010), ID: Inter Dimensi (2012), Empayar (2013) and Bedar Tanpa Laut (2015). 
His first work, Kembara Amira, won first place in the teen novel writing competition, Utusan-ExxonMobil Literature Prize, in 2005 (Utusan Online, 2006). His latest novel, Mengukir Larut (2016), clearly shows his maturity and transformation in novel writing.

According to the Encyclopaedia Britannica (2013), a historical novel is one that has history as its background and describes the atmosphere, culture and social situation of the past with realistic and true details based on historical facts. The novel's appeal and uniqueness are due to the writer's language style such as the use of metaphors, natural images, appropriate selection of words as well as a chronological narration that is presented in a realistic and apt manner in accordance with true historical facts. These elements have inspired the researcher to examine and understand more deeply the issues presented in Mengukir Larut.

Mengukir Larut is a 167-pages novel that revolves around the conflicts, struggles and squabbles between two secret societies, namely Ghee Hin and Hai San, that were feuding over tin mining areas in Kelian Pauh, Larut. The fights caused the local Malay chiefs in Larut to encounter administrative conflicts. The most disturbing incident was when the British interfered in the administration of Perak. Internal problems such as greed, arrogance and envy that infected the local chiefs made the conflict and power struggle difficult to resolve. The conflict became even more complicated due to the external interference of the British, who had their own agenda. British attempts to influence and incite the local chiefs in the system of administration and their desire to exploit the rich resources of the state caused the conflict to become more dire and prolonged, which culminated in the foreigners controlling Perak.

For the analysis of Mengukir Larut, as a starting point, the researcher has chosen the Management Approach put forward by Mohamad Mokhtar Abu Hassan (2013). Although this approach contains five important principles, namely planning, leadership, organization, staffing and control, this study focuses on one principle only, which is the planning principle.

\section{THE METHODOLOGY OF THE STUDY}

The methodology used in this study is that of literature review and textual analysis. The literature involved are secondary sources such as texts, websites and relevant reference books. The textual analysis is done by reading in detail the selected novel and identifying several important events related to 
the planning principle. The focus of the analysis is to exhibit the presence of the planning principle in the identified events.

\section{THE MANAGEMENT APPROACH IN LITERARY WORKS}

The initial idea of the Management Approach in literary works by Mokhtar Abu Hassan was first presented at the Himpunan Ilmuwan Sasterawan Melayu seminar at Sultan Idris Education University (UPSI), Tanjung Malim, Perak, in 2013. It was further streamlined in his inaugural lecture, which he presented on 4th August 2016 at the Malay Studies Academy, Universiti Utara Malaya (UUM).

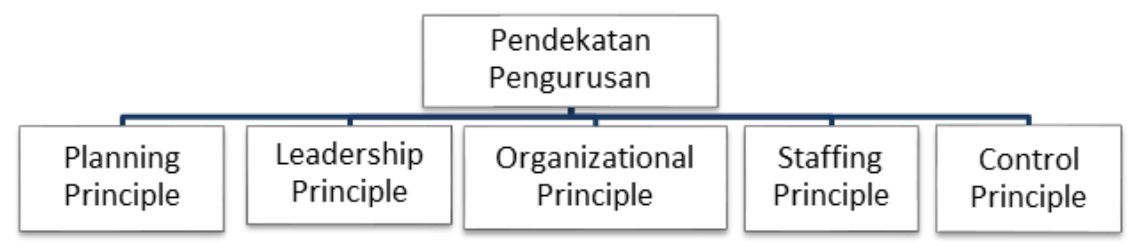

Figure 1 Management Approach.

Based on Figure 1, the Management Approach contains five principles, namely planning, leadership, organization, staffing and control. This new approach not only makes the world of literary criticism more interesting, but it also can teach the public and raise their awareness of the importance of management in creating a more planned and structured lifestyle (Mohamad Mokhtar, 2016, p. 3).

Studies related to the Management Approach can be observed from working papers that have been presented and published. Mohamed Zuber (2017) used this approach in his doctorate thesis at the University of Malaya (UM) entitled "Cerita Lipur Lara Terpilih Berdasarkan Pendekatan Pengurusan". In 2015, Mohamed Zuber, Sara and Mohamed Mokhtar carried carried out a study entitled "Kepimpinan dalam Hikayat Awang Sulung Merah Muda" from the management perspective. This study was published in Volume 26 of Jurnal Akademi Pengajian Melayu by UM in 2015. Another study by Mohamed Zuber, Sara and Mohamad Mokhtar in 2015 entitled "Keintelektualan Pemikiran Melayu dalam Cerita Lipur 
Lara: Penelitian Awal Berdasarkan Perspektif Pendekatan Pengurusan" was published in the same year in Journal of Business and Social Development by University Malaysia Terengganu (UMT).

Another study related to the Management Approach by Mohamad Zuber and Mohamad Mokhtar entitled "Dimensi Perancangan dalam Hikayat Malim Dewa" was published in Volume 27 of Jurnal Akademi Pengajian Melayu by UM in 2016. In addition, Mohamad Zuber and Mohamad Mokhtar carried out a Management Approach study entitled "Prinsip Perancangan dalam Hikayat Awang Sulung Merah Muda", which was published in Volume 5 of Journal of Business and Social Development by UMT in March 2017. Sara Beden conducted a study using the Management Approach in her article entitled "Perancangan Bestari dalam Hikayat Khoja Maimun: Aplikasi Prinsip Perancangan dalam Pendekatan Pengurusan", which was published in Malay Literature by Dewan Bahasa dan Pustaka in 2018.

The researcher has focused his study on one principle only, which is the planning principle. The planning principle found in Mengukir Larut is dominant due to the various important events requiring the implementation of strategy by the main and supporting characters in order to realize their objectives.

\section{THE PLANNING PRINCIPLE}

Harold Koontz and Heinz Weihrich (1997, p. 58) define planning as a process of management that involves selecting a mission, determining the objective and drawing up an action plan to achieve the objective. At the same time, planning involves the process of making decisions, that is, deciding on action plans. Dessler $(2013$, p. 4) defines planning as a detailed method that is prearranged prior to performing or executing an action. Decenzo and Robbins $(1999$, p. 31) explains that planning is a process that involves identifying the objectives or goals of an organization, creating an overall strategy to achieve the goals and developing an overall plan to streamline and integrate all the activities of the organization. Daft (1997, p. 5) defines planning as a process of determining objectives and deciding on the things that must be done in order to achieve those objectives. Based on these definitions, it is clear that planning requires several steps or strategies to find solutions in order to achieve the desired objectives.

With these definitions as a starting point, Mohamad Mokhtar (2013) defines the stages of planning as shown in Figure 2: 


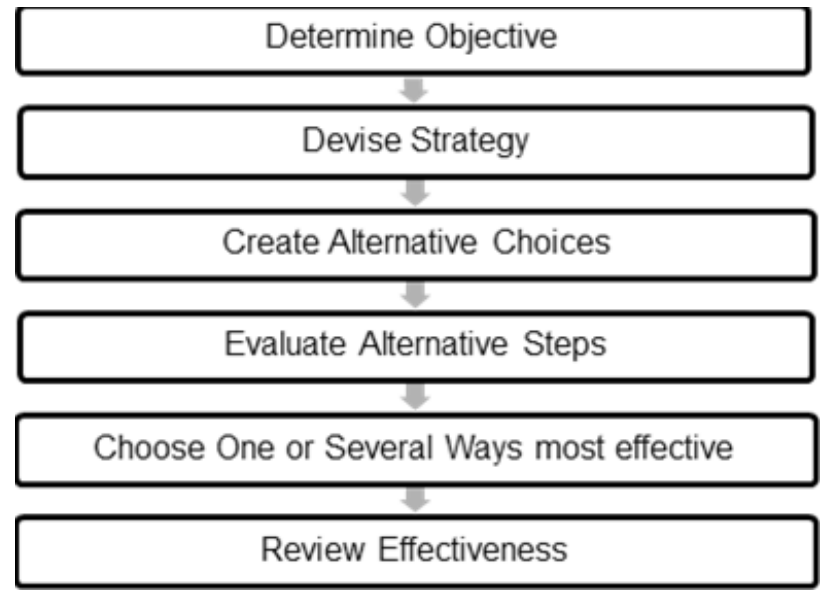

Figure 2 Stages in planning.

(Source: Pendekatan Pengurusan dalam Kritikan Kesusasteraan, 2016, p. 18)

Based on Figure 2, the planning principle is made up of several stages. These stages include determining objectives, devising strategies, creating alternative choices, evaluating alternative steps, choosing one or several ways that are most effective and reviewing its effectiveness. The focus of this study is to examine the stage of planning that is carried out by a character in order to realize his objective. This stage of planning is the measure in determining the effectiveness of the objective's achievement that has been targeted by the main and supporting characters in the text studied. This study is aimed at identifying and demonstrating the presence of the planning principle and analysing it through the main and supporting characters in Mengukir Larut based on the Management Approach.

\section{CLASSIFICATION OF RESEARCH DATA}

Mengukir Larut shows a high tendency of the presence of the planning principle in the Management Approach by Mohamad Mokhtar (2013) in its characters through the important events narrated. These events are as follows:

Event 1: British Plan to Control Perak

Event 2: Ngah Ibrahim's Plan to Resolve Conflict between the Ghee Hin and Hai San Secret Societies 
Event 3: Raja Muda Abdullah's Plan to Ascend the Throne of Perak

Event 4: Local Malay Chiefs' Plan to Stop J.W.W. Birch's Interference in the Administration of Perak

All the important events mentioned above are analysed using the planning principle. The planning principle, as applied by the characters in Mengukir Larut, is analysed according to its different stages, namely that of determining objectives, devising strategies, evaluating the alternative choices, choosing one or several methods and reviewing its effectiveness.

\section{PLANNING IN MENGUKIR LARUT}

\section{Event 1: British Plan to Control Perak}

The event that shows the presence of planning in Mengukir Larut is the British plan to control Perak and its wealth. The British, who were led by the Governor of the Straits Settlements, Major General Orfeur Cavenagh, had set their objective to control Perak and its resources. In order to realize his plans, Orfeur Cavenagh devised a strategy in which Lee Coyen, the head of the Ghee Hin secret society, would become his stepping stone to help him accomplish his goal. Lee Coyen's vengeance for the death of his clan members during Hai San's attack was used by the British to interfere in the administration of Perak since the government of Perak led by Sultan Jaafar had failed to handle the conflicts and clashes that erupted between the two secret societies. As a result, the British used the strategy of asking Sultan Jaafar to pay a high compensation to the Ghee Hin society. In this matter, Sultan Jaafar was blamed by the British for the dispute that took place in Perak under his administration. The issue of compensation imposed by the British became the first step towards realizing their objective to control Perak, as observed in the following excerpt:

Segala-galanya terjadi seperti yang telah dirancang. Konspirasi untuk menguasai Larut sedang dirancang dengan penuh perasaan haloba. Kumpulan kongsi gelap mahukan bijih timah dan Inggeris mahukan kuasa politik lalu merampas hak itu daripada pembesarpembesar Perak. 
"Kita perlu mengenakan suatu bayaran yang tidak mampu dibayar oleh Sultan Jaafar. Jika dia gagal, mudahlah kita mengenakan syarat tambahan dan usaha untuk bertapak di Perak, terutamanya Larut akan menjadi semakin mudah.” Tiba-tiba sahaja Orfeur Cavenagh bersuara sambil meletakkan surat daripada Sultan Perak.

[Everything happened as planned. The conspiracy to control Larut was being planned with a lot of greed. The secret societies wanted tin and the British wanted political power, which they then seized from the local chiefs of Perak.

"We need to impose a compensation from Sultan Jaafar which he is not able to afford. If he fails, it's easy for us to impose additional terms and efforts to establish a footing in Perak, especially Larut which would become even easier." Orfeur Cavanagh interjected suddenly, as he lays down a letter from Sultan Jaafar.]

(Mengukir Larut, 2016, pp. 23 - 24)

The imposition of a high compensation by the British failed to achieve their objective. Their strategy failed because Sultan Jaafar was able to pay the amount with the help of Ngah Ibrahim, the Minister of Larut. The failure of their first strategy did not dampen the British, who subsequently came up with an alternative plan to realize their objective.

Under their new governor, Andrew Clarke, and assisted by Braddel, the attorney general for the Straits Settlements, the British chose an alternative way to achieve their goal of ascending Raja Muda Abdullah to the Perak throne instead of Sultan Ismail. In order to realize this objective, Andrew Clarke resorted to wiles by drawing up the contents of an agreement to be signed by the local Malay chiefs who were inclined towards British interests. Andrew Clarke's alternative choice was appropriate and relevant to the political situation then, as Raja Muda Abdullah was in desperate need of British aid in order to ascend the throne of Perak. The alternative choice by the British in order to control Perak can be gleaned from this excerpt:

"Braddel, kau pastikan setiap syarat perjanjian itu memberi kekuatan
kepada kita." Andrew Clarke segera mengingatkan Braddel, peguam
negara bagi Negeri-Negeri Selat. Andrew Clarke tahu kemampuan
Braddel tetapi sengaja dia ingatkan perkara itu. Braddel mengangkat
ibu jarinya. "Kita selesaikan masalah takhta Perak. Itu yang utama. 
Raja Muda Abdullah telah berjanji akan membenarkan kita masuk ke negeri Perak. Jadi saya pastikan kedudukan raja itu lebih kukuh."

["Braddel, make sure the terms of the agreement favour us." Andrew Clarke quickly reminds Braddel, attorney general for the Straits Settlements. Andrew Clarke knows Braddel's capability but he deliberately reminds him of the matter. Braddel raises his thumb. "We will solve the Perak throne issue. That is the main thing. Raja Muda Abdullah has promised to allow us to enter the state of Perak. So, I will ensure the position of the raja is stonger."]

(Mengukir Larut, 2016, p. 119)

The evaluation of their alternative choice made the British confident that Perak could come under their control. From this evaluation, the British effectively reinforced their efforts of supporting and assisting Raja Muda Abdullah by imposing several terms of agreement that favoured them. Consequently, after the agreement was signed, indirect British interference in the administration of Perak began. The contents of the agreement allowed the British to take over the collection of taxes from the local Malay chiefs and Raja Muda Abdullah had to accept a Resident as his adviser. The evaluation on this alternative step can be observed in the following excerpt:

"Mahukah Sultan menerima cadangan ini, tuan gabenor?" soal Braddel kerana dia agak sangsi dengan syarat perjanjian itu. "Bukankah kita mahu Sultan membayar gaji dan menyediakan sebuah rumah untuk pegawai ini. Saya rasa mereka akan menolak syarat ini." "Braddel!" sergah Andrew Clarke lalu meneguk air. "Kita diminta oleh mereka. Mereka perlukan kita. Jadi kita harus ambil kesempatan ini. Biarlah Raja Abdullah fikirkan cara untuk membayar gaji kepada pegawai yang bakal dilantik nanti."

["Will the Sultan accept this proposal, Governor?" Braddel asked because he was doubtful of the the terms of the agreement. "Don't we want the Sultan to pay the salary and provide a house for this officer. I feel that they will reject this term." "Braddel!" Andrew Clarke interrupted as he gulped down some water. "We have been asked by them. They need us. So, we should take this opportunity. Let Raja Abdullah worry about how to pay the officer who is to be appointed".]

(Mengukir Larut, 2016, p. 122) 
This instance of British success affirmed their administrators' charisma and integrity in planning effective strategies to achieve control of Perak. Their creative idea as well as detailed planning reveal a visionary and farreaching thinking process in pursuit of their objective, which was to control Perak that is rich in resources. Their care in drawing up a strategy by taking into account external factors such as the policies of the Colonial Land Office and the existing situation then, which was the feud over the throne in Larut, also contributed to their success. This is consistent with the definition of planning by Azman (2013, p. 77), who defines it as a process of determining the desired objective and then devising the best action strategy by taking into consideration the internal factors of the organization and the external environment that influences the organization to achieve its objectives.

\section{Event 2: Ngah Ibrahim's Plan to Resolve Conflict between the Ghee Hin and Hai San Secret Societies}

Based on the analysis of the event involving Ngah Ibrahim in resolving the conflict between the Ghee Hin and Hai San secret societies, an important feature that the characters do in order to achieve their objectives emerges, which is planning. Systematic and smart planning was carried out by Ngah Ibrahim in resolving the conflict between these two secret societies. Ngah Ibrahim, as the minister of Larut, devised a strategy that would separate the two societies by evicting one of them from Larut. This strategy was deemed appropriate based on the political and economic situation in Larut at that time. The separation of the societies would ensure the security and trade of Larut. Ngah Ibrahim's plan demonstrates his leadership and vision in resolving the conflict between the two secret societies in Larut that had caused losses to the state. This event can be observed in the excerpts below:

"Jika berdua mereka saling berebut dan entah berapa lama keadaan ini akan berterusan. Tidak salah jika kita halau salah satu daripada mereka. Tinggal satu puak sahaja dan lebih mudah kita hendak uruskan pelombong-pelombong itu."

["If there are two of them, they will fight and this will go on and on. It's not wrong that we evict one of them. With just one faction left, it is easier to manage the miners.] 
"Lebih mudah menguruskan jumlah manusia yang kecil berbanding yang ramai!" tegas Ngah Ibrahim. Kini Ngah Lamat faham. Memang benar jumlah Hai San amat kecil berbanding Ghee Hin. Memang pintar Menteri Larut dalam membuat keputusan. Andaian Ngah Lamat ternyata meleset. Bukan sejarah hubungan Long Jaafar dan Hai San yang menjadi punca, sebaliknya strategi pentadbiran.

["It's easier to manage a small number of people as opposed to many," stressed Ngah Ibrahim. Now Ngah Mamat understands. It's true that the Hai San is smaller in number compared to Ghee Hin. The Minister of Larut is really smart in making decisions. Ngah Lamat's assumption is clearly wrong. It's not the history of Long Jaafar's relationship that is the cause, but it is the administrative strategy.]

(Mengukir Larut, 2016, p. 52)

"Halau semua Ghee Hin, panglima!" Ngah Ibrahim segera memberi kebenaran. "Biar putih tulang jangan putih mata!"

["Evict all Ghee Hins, commander!" Ngah Ibrahim quickly gave the the orders. "Death is better than failure."]

(Mengukir Larut, 2016, p. 53)

However, the strategy devised by Ngah Ibrahim to separate the secret societies and end the feud gave rise to other problems. The negative implication from this strategy made the conflict even worse when the Ghee Hin society made him their enemy (Mengukir Larut, 2016, p. 69).

As the conflict erupted, Ngah Ibrahim chose an alternative way to achieve his objective by appointing an English officer, Captain Tristam Charles Sawyer Speedy, to calm the situation. Ngah Ibrahim's purpose was to resolve the conflict and strengthen the security system of Larut. His decision showed a high tendency of achieving an objective that has been planned. This is consistent with the view (Azman, 2003, p. 86) that decision making is a process of searching and selecting the best option among several alternative choices to resolve a conflict. The alternative taken by Ngah Ibrahim was the result of an advice given by Harry Ord, the Governor of the Straits Settlements. This can be seen in the following excerpt: 


\section{MALAY LITERATURE VOLUME 32 NUMBER 1 JUNE 2019}

Cuma dia syorkan Larut mengambil seorang pegawai Inggeris untuk kuatkan sistem keselamatan. Persaingan kongsi gelap semakin hebat. Begitu juga usaha-usaha yang dilakukan oleh Raja Muda kita. “Perlukah Dato' berbuat begitu?" soal Dato' Sagor penuh dengan rasa risau. Dia khuatir Gabenor Inggeris itu juga mempunyai agenda yang tersembunyi."

"Kita usahakan juga dengan harapan Inggeris tahu kita mampu memerintah. Kita mampu mengawal kongsi gelap dan kita mampu mempertahankan sistem beraja kita. Biar mereka lihat kesungguhan kita untuk mentadbir," jelas Ngah Ibrahim. Sebenarnya dia amat mempercayai nasihat sahabat baiknya, Harry Ord.

[Except that he suggested Larut takes a British officer to strengthen the security system. The feud between the secret societies has intensified. So too, the efforts done by our Raja Muda. "Is it necessary for Dato' to do this?" asks Dato' Sagor full of anxiety. He is worried that the English Governor also has a hidden agenda.

"We go forward with the hope that the British know we are able to govern. We are able to control the secret societies and we are able to uphold our monarchical system. Let them see our commitment to govern," says Ngah Ibrahim. In fact, he fervently believed in the advice given by his good friend, Harry Ord. ]

(Mengukir Larut, 2016, p. 89)

The action taken by Ngah Ibrahim, which is to allow a British officer to monitor the safety of Larut, was questioned by Dato' Sagor. This prompted Ngah Ibrahim to clear such doubts by evaluating the appropriateness of the alternative action. The conversation between Dato' Sagor and Ngah Ibrahim about evaluating this alternative step can be observed in the following excerpt:

“Tidak cukupkah panglima dan pendekar kita, Dato'?” soal Dato' Sagor kerana dia tahu sahabatnya akan berbelanja besar untuk mendapatkan lelaki Inggeris itu.

"Cukup. Malah hebat. Kehebatan mereka dengan terakul dan pemuras. Lela dan rentaka. Cuma kita perlukan seorang pentadbir dan saya mahu tentera kita dimodenkan. Malah sekarang dia berada 
di India kerana mahu membawa masuk 110 sepoi dari India. Katanya dari Punjab. Malah dia mohon sejumlah wang untuk dapatkan Meriam jenis Krupps. Meriam sama yang pernah digunakan oleh Empayar Islam Uthmaniah," jelas Ngah Ibrahim bersungguhsungguh.

"Jadi kita gabungkan tentera dari India dan tentera Melayu Larut, sudah pasti keamanan Larut akan kekal lama. Jika berlaku pergaduhan antara Ghee Hin dan Hai San, saya tidak ragu-ragu akan menggunakan kekuatan tentera ini untuk membanteras mereka.

["Are there not enough warriors and fighters among us, Dato"? asked Dato' Sagor because he knew his friend would have to spend a huge amount of money to get a British officer.

"Quite enough. In fact, excellent ones too. Their great skill with pistols and blunderbuss. Cannons and swivel guns. But we need an administrator and I want our army to be modernised. He is now in India to recruit 110 sepoys from India. He says from Punjab. And he has asked for a sum of money to buy the Krupps cannon. The same cannons used by the Uthmaniyh Islamic Empire," he explained fervently.

"So, we combine the army from India and the Malay troops from Larut, then we can ensure the continuous safety of Larut. If a fight breaks out between Ghee Hin and Hai San, I will not hesitate to use the combined army to end the fight."]

(Mengukir Larut, 2016, p. 91)

Nevertheless, the strategy that was expected to be effective was unable to calm the situation; in fact, Larut became even more chaotic. Ngah Ibrahim was deceived by Harry Ord's pleas to take in a British officer to administer the security of Larut. This decision further complicated the economic and political situation in Larut. Ngah Ibrahim had to review the effectiveness of his strategy, as observed in the following excerpt:

Dia telah melihat permainan mereka. Dia masih ingat bagaimana Harry Ord, bekas Gabenor Negeri-Negeri Selat; memujuknya agar mengambil Kapten Speedy untuk dijadikan Ketua Polis di Larut agar Inggeris mengagumi cara pentadbirannya. Dia akur dengan pujukan 
itu dan memberi sejumlah gaji yang tidak mampu dibayar oleh Inggeris kepada mana-mana pegawainya. Tetapi keadaan sebaliknya berlaku. Speedy amat lemah. Gagal menyelesaikan masalah Ghee Hin yang menguasai Simpang. Malah mengesan niat jahat Ghee Hin Pulau Pinang menyerang dan membakar rumahnya di pulau itu. Sepatutnya Speedy memiliki maklumat kerana Speedy adalah bekas pegawai polis di pulau itu. Kini Speedy diambil bekerja dengan J.W.W. Birch. Mungkin Speedy adalah pengintip bagi mereka.

[He has seen their tricks. He remembers how Harry Ord, the former governor of the Straits Settlements pleaded with him to take in Captain Speedy as the Chief of Police in Larut to impress the people of his administration. He agreed to the pleas and gave a salary which the British were unable to give their own officers. But the opposite happened. Speedy was weak. Failed to resolve the problem involving the Ghee Hins, who had control over Simpang. He also discovered the Penang Ghee Hins' evil intention of attacking and burning down his house on the island. Speedy should have had the relevant information as he was the ex-police officer in Penang. Now Speedy was working with J.W.W. Birch. Perhaps Speedy was spying for them.]

(Mengukir Larut, 2016, p. 143)

Based on this event, it is obvious that Ngah Ibrahim failed in his planning by acting hastily in deciding to take in a British officer. As a visionary leader, he should have been more cautious and aware of the wiles played by the British, who were always waiting for the opportunity to control Perak. According to Mohamad Zuber and Mohamad Mokhtar (2017, p. 132), the result of a process of an activity in accomplishing its goal effectively and efficiently is determined by well-thought-out planning. Therefore, Ngah Ibrahim, as the leader of Larut, should have acted in a more mature and intelligent manner in dealing with these administrative problems. Smart management is essential for achieving goals.

\section{Event 3: Raja Muda Abdullah's Plan to Ascend the Throne of Perak}

The following event demonstrates the planning principle in the character of Raja Muda Abdullah. Raja Muda Abullah sets his objective, which is to ascend the throne of Perak. In order to achieve his objective, he came up 
with various strategies to dethrone Sultan Ismail. One strategy was to force the local Malay chiefs to sign a letter as proof of their support of him. This strategy worked smoothly because the nobles signed the letter, knowing that he was the rightful heir to the throne of Perak and to avoid any conflict and dispute with him. The letter of agreement was submitted to Harry Ord as proof that Raja Muda Abdullah had the support of the local Malay chiefs. This can be gleaned in the following excerpt:

\begin{abstract}
"Tengku, mengikut pengetahuan patik Sultan Ismail itu bukan keturunan raja. Sebaliknya keturunan sayyid dari Siak. Dia tidak layak menjadi Sultan. Jadi, Tengku perlu dapat persetujuan beberapa orang pembesar untuk meminta bantuan Inggeris bagi selesaikan kemelut ini." Itulah cadangan Kulop Hamzah sebelum pergi meninggalkan Istana Purbayan bersama sangkar tekukur kesayangan Raja Muda. Tidak perlu dia ceritakan kepada Meor. Dia hanya perlu bertindak mendapatkan sokongan beberapa orang pembesar. Kulop Hamzah berjanji akan menguruskan surat itu dengan pegawai Inggeris yang paling berkuasa di Negeri-Negeri Selat.
\end{abstract}

["Tengku, to my knowledge, Sultan Ismail is not of royal descent. In fact, he is descended from the Sayyid family from Siak. He is not qualified to be Sultan. Therefore, Tengku should get the agreement from some local chiefs to ask for help from the British to settle this conflict." That was the suggestion of Kulop Hamzah before leaving Purbayan Palace with raja Muda's beloved cuckoo bird's cage. There was no need to inform Meor. He just had to get the support of several local chiefs. Kulop Hamzah promised to write a letter to the most powerful British official in the Straits Settlements.]

(Mengukir Larut, 2016, pp. 77 - 78)

However, the strategy executed by Raja Muda Abdullah seemed to have reached a dead end when Harry Ord did not come to his aid as he had received a warning from the Colonial Land Office that outside parties could not interfere in any of the Malay states (Mengukir Larut, 2016, p. 106). Even though Raja Muda Abdullah's strategy failed, he did not give up hope and, instead, came up with another alternative plan, which was to appeal for assistance from Andrew Clarke, the new Governor of the Straits Settlements. Andrew Clarke's appointment renewed Raja Muda Abdullah's hope to realize his objective. This can be seen in the following excerpt: 
"Ya, Andrew Clarke. Dia dilihat lebih berkarisma untuk membantu Inggeris masuk ke dalam negeri. Davidson akan membantu kita merangka surat buat Clarke. Tengku hanya membuat drafnya sahaja. Biar dia yang tulis kerana dia lebih tahu menulis surat yang sesuai untuk berurusan dengan Inggeris." Kim Cheng mula menjelaskan perancangannya. Dia mahu Davidson sahaja yang menulis dan Raja Muda Abdullah hanya perlu tandatangan surat itu. Raja Muda Abdullah akur dengan cadangan Kim Cheng dan dia amat gembira. Jika sebelum ini Harry Ord mengecewakannya, dia amat berharap Andrew Clarke akan merealisasikan keinginannya.

["Yes, Andrew Clarke. He is seen as a more charismatic person to help the British enter the state. Davidson will help us write a letter to Clarke. Tengku just needs to draft it. Let him write because he knows better how to deal with the British." Kim Cheng started to explain his plan. He wanted Davidson only to write and Raja Abdullah only needed to sign it. Raja Muda Abdullah agreed with Kim Cheng's plan and was very pleased. If Harry Ord had disappointed him, he really hoped that Andrew Clarke would help him get what he wanted.]

(Mengukir Larut, 2016, p. 113)

The alternative choice taken by Raja Muda Abdullah shows a high tendency towards the achievement of the objective. This is consistent with Azman's view (2003, p. 86) that inaccurate planning will lead one in the wrong direction. Raja Muda Abdullah's implementation of the alternative choice attracted the attention of Andrew Clarke, who agreed to help Raja Muda Abdullah to ascend the throne of Perak. However, several additional terms were imposed on Raja Muda Abdullah in order to facilitate the expansion of British influence in the political administration of Perak. The British acknowledgement of Raja Muda Abdullah as the new Sultan of Perak can be observed in the following excerpt:

\footnotetext{
"Inggeris mahu mengiktiraf Raja Muda Abdullah sebagai Sultan yang baru!" Tingkah Andrew Clarke penuh bangga. Jawapan itu agak mengejutkan kerana Inggeris tidak mempunyai apa-apa kuasa untuk masuk campur dalam urusan pelantikan sultan baru.
} 
["The British want to acknowledge Raja Muda Abdullah as the new Sultan!" said Andrew Clarke proudly. It was a surprising answer since the British does not have any power in the appointment of a new Sultan.]

(Mengukir Larut, 2016, p. 127)

The planning in this event clearly shows that Raja Muda Abdullah was someone who did not lose hope easily as he continued to plan in order to accomplish his goal. Although his alternative plan was a form of coercion because it involved dethroning Sultan Ismail without consensus or royal ceremony, the planning that involved several activities (strategies) enabled the achievement of his objective. This is consistent with the definition of planning, which involves a comprehensive chain of activities in achieving various goals that have been determined (Azman, 2003, p. 84). Clearly, Raja Muda Abdullah succeeded in achieving his goal as a result of the effectiveness of the stages of planning that were implemented.

\section{Event 4: Local Malay Chiefs' Plan to Stop J.W.W. Birch's Interference in the Administration of Perak}

The main objective of the local Malay chiefs was clearly to stop J.W.W. Birch's interference in the administrative affairs of Perak. After their objective was determined, they had to plan a strategy to realize their objective. The setting of an objective and strategy by these chiefs is consistent with the definition of planning by Daft (1997, p. 5), which is a process of setting an objective and determining what must be done in order to achieve that objective. The Chief Minister had drawn up a strategy, which was to propose that Sultan Abdullah write a letter to Andrew Clarke in order to report J.W.W. Birch's interference in the administration of Perak. This strategy was agreed upon by Sultan Abdullah and all the Malay chiefs, including the Harbourmaster, Dato' Maharaja Lela, and Ngah Ibrahim. This can be seen in the following excerpt:

“Bagaimana jika kita mengutus sepucuk surat kepada Clarke," Tibatiba Bendahara memberikan cadangan. Semua pembesar memerhati Bendahara menanti cadangannya, "kita laporkan tindakan Birch. Dia juga menyalahi syarat perjanjian. Dia hanya ditugaskan menasihati dan bukannya campur tangan dalam urusan pentadbiran Perak. Amat jelas sekali, Birch juga melanggar syarat-syarat yang 
telah dipersetujui. Kerana tingkah lakunya menyebabkan keadaan menjadi rumit begini."

"Betul kata Bendahara. Itulah tindakan sebaiknya, tuanku!" tambah Syahbandar dan disokong Dato' Maharaja Lela serta Ngah Ibrahim.Akhirnya sepucuk surat bantahan dibawa ke Singapura dan disertai oleh Raja Idris ibni Almarhum Raja Bendahara Alang Iskandar, Laksamana Muhammad Amin dan Encik Muhammad Arshad.

["What if we write a letter to Clarke," the Chief Minister quickly suggested. All the nobles waited for his proposal, "we report Birch's actions. And he did go against the terms of the agreement. He was tasked only with advising and not meddle with the governing of Perak. It's very clear that Birch violated the terms that have been agreed upon. Due to his behaviour, the situation has become more difficult."

"You are right, Chief Minister. That is the best action to take, Your Highness!" added the Harbourmaster and supported by Dato' Maharaja Lela and Ngah Ibrahim. In the end, a protest letter was brought to Singapore, accompanied by Raja Idris ibni Almarhum Raja Bendahara Alang Iskandar, Laksamana Muhammad Amin and Encik Muhammad Arshad.]

(Mengukir Larut, 2016, pp. 154 - 155)

The strategy used shows the effort and cooperation among the local Malay chiefs who were united in the pursuit of their objective. However, this strategy failed because the letter sent was ignored by Andrew Clarke, who sided with J.W.W. Birch. After the failure of this strategy, all the Malay chiefs discussed an alternative step, which was to kill J.W.W. Birch. This plan was a drastic decision made by the local Malay chiefs to stop British interference. J.W.W. Birch's pride, arrogance, rudeness and lack of appreciation for Malay customs and culture intensified the hatred of these Malay chiefs. This matter is revealed in the following excerpt:

"Usaha memujuk sudah sampai ke pengakhirannya. Jadi apa lagi yang mampu kita lakukan?" "Bunuh!" cadang Dato'Maharaja Lela. Beberapa pembesar tersentak. Tanpa mereka duga, Dato' Maharaja Lela berfikir begitu. "Bunuh sahaja lelaki Inggeris itu! Dia bertindak membuang Syahbandar. Kemudian dia mengarahkan rumah Raja 
Ngah dibakar kerana memungut cukai di Bidor. Bukankah Raja Ngah adalah saudara kepada Sultan Ismail. Tanah Bidor adalah tanah tauliah Sultan kepada Raja Ngah."

["Our efforts to persuade have come to an end. What else can we do?" "Kill!" Dato' Maharaja Lela proposed. Several local chiefs were shocked. They did not anticipate Dato' Maharaja Lela to be thinking that way. "Just kill that British man! He's trying to remove the Harbourmaster. Then he instructed Raja Ngah's house to be burned for collecting taxes from Bidor. Isn't Raga Ngah a relative of Sultan Ismail. Bidor is the Sultan's hereditary land given to Raja Ngah."]

(Mengukir Larut, 2016, p. 159)

Based on this excerpt, it is clear that the local Malay chiefs unanimously agreed to take the alternative action of killing J.W.W. Birch. Subsequently, they evaluated the alternative step in order to ensure the smooth execution of their plan. The episode where the alternative step is evaluated is seen in the following excerpt:

"Jika gagal cadangan Laksamana, bagaimana jika kita serang sahaja Bandar Baharu. Biar hancur bagai dilanda geroda, " tingkah Dato' Sagor sambil memberi cadangan.

"Kita kekurangan senjata, Dato,," Laksamana mencelah. Dia tahu kekuatan Inggeris di Bandar Baharu.

"Begini sahajalah," Tiba-tiba Sultan Abdullah bersuara. Dia tahu pendapat demi pendapat tidak akan menyelesaikan masalah. "Dato' Maharaja Lela sudah pasti mahu bunuh lelaki itu. Kita bertemu lagi selepas ini. Berfikir dahulu. Jika gagal kita main hantu. Pilih cadangan terbaik."

["If the admiral's proposal fails, why don't we attack Bandar Baharu. Let us raze it to the ground," Dato Sagor interjected while making a suggestion.

"We lack arms, Dato"” the admiral responded. He knew the power of the British in Bandar Baharu.

Sultan Ahmad quickly said: "Wait". He knew that these views will not solve the problem. "Dato' Maharaja Lela will certainly want to 
kill that British man. We meet again after this. Think first. If that fails, we do the worst. Choose the best proposal.']

(Mengukir Larut, 2016, p. 161)

As a result of evaluating the alternative step, the local chiefs became committed to kill J.W.W. Birch. This strategy is said to have been the most appropriate in order to get rid of Birch's arrogance and interference. Finally, after detailed planning, Dato' Maharaja Lela succeeded in killing J.W.W. Birch. Based on the evaluation of the alternative step, it shows detailed planning as well as cleverness on the part of the local chiefs in the effort to achieve their common goal. Although the strategy to kill, which was executed by the characters of the local Malay chiefs, was negative in nature, the aspect to be highlighted is the planning. A systematic and orderly planning enabled them to overcome the problems that hindered the realization of their objective. This is consistent with the definition of planning, which is a detailed method that is predetermined before doing something or embarking on a particular action (Dessler, 2013, p. 4).

\section{CONCLUSION}

Based on the the study's analysis using the Management Approach in the novel Mengukir Larut, the results show a high inclination in support of the planning principle. A detailed examination and analysis of the events in Mengukir Larut reveal the usage of the planning principle. The stages in planning such as determining objectives, devising strategies, alternative choices, alternative evaluation and choosing one or several ways are the dominant steps revealed in the text studied. It is therefore consistent with the planning principle put forth by Mohamad Mokhtar (2013). The reconstruction of the management aspect in this research text, particularly that of planning, is a platform that can open up a new page and dimension in the world of literary criticism in the country. 


\section{REFERENCES}

Amer Hmzah L. Kadir. (2016). Mengukir Larut. Kuala Lumpur: Dewan Bahasa dan Pustaka.

Ani Awang. (2006). Kembara Amira hadiah pertama kategori novel remaja. Retrieved on 2 April 2018 from http://ww1.utusan.com.my/utusan/info. $\operatorname{asp} ? \mathrm{y}=2006 \& \mathrm{dt}=0713 \& \mathrm{pub}=$ Utusan_Malaysia\&sec $=$ Sastera\&pg $=$ sa_01. htm.

Azida Ishak. (2016). Wawancara bersama Amer Hmzah L. Kadir Bahagian 1. Retrieved on 3 April 2018 from https://penasaifai.com/2016/02/25/ wawancara-bersama-amer-hmzah-l-kadir-bahagian-1/.

Azman Che Omar. (2003). Pengurusan di Malaysia dari perspektif Islam. Kuala Lumpur: Dewan Bahasa dan Pustaka.

Daft. (2010). Management. United States of America: South-Western Cengage Learning.

Decenzo \& Robbins. (2010). Fundamentals of human resource management. United States of America: Pearson.

Dessler, Gary. (2013). Human resource management. United States of America: Prentice Hall.

Koontz, Harold \& Heinz Weihrich. (1987). Pengurusan. Translated by Mohd. Salmi Mohd. Sohod, Siti Nadzrah Sheikh Omar. Kuala Lumpur. Dewan Bahasa dan Pustaka.

Mohamad Mokhtar Abu Hassan. (2013). Pendekatan pengurusan: Satu metode dalam kritikan sastera. Himpunan Ilmuwan Sastera Melayu Malaysia Kedua, Universiti Perguruan Sultan Idris, Tanjung Malim, 4 - 5 October, 2013.

Mohamad Mokhtar Abu Hassan. (2016). Syarahan perdana pendekatan pengurusan dalam kritikan kesusasteraan. Kuala Lumpur: Akademi Pengajian Melayu, Universiti Malaya, 4 August 2016.

Mohamad Zuber Ismail \& Mohamad Mokhtar Abu Hassan. (2016). Dimensi perancangan dalam Hikayat Malim Dewa. Jurnal Pengajian Melayu, 27, 1-19.

Mohamad Zuber Ismail \& Mohamad Mokhtar Abu Hassan. (2017). Prinsip Perancangan dalam Hikayat Awang Sulung Merah Muda. Journal of Bussines and Social Development, 5, 129-139.

Mohamad Zuber Ismail, Sara Beden \& Mohamad Mokhtar Abu Hassan. (2015a). Kepimpinan dalam Hikayat Awang Sulung Merah Muda dari perspektif Pendekatan Pengurusan. Jurnal Pengajian Melayu, 26, 66-95.

Mohamad Zuber Ismail, Sara Beden \& Mohamad Mokhtar Abu Hassan. (2015b). Keintelektualan Pemikiran Melayu dalam Cerita Lipur Lara: Penelitian Awal Berdasarkan Perspektif Pendekatan Pengurusan. Journal of Bussines and Social Development, 3, 1-16. 
MALAY LITERATURE VOLUME 32 NUMBER 1 JUNE 2019

Mohamad Zuber Ismail. (2017). Cerita lipur lara terpilih berdasarkan Pendekatan Pengurusan (Unpublished Ph.D's thesis). Universiti Malaya.

Sara Beden. (2018). Prinsip perancangan dalam Hikayat Khoja Maimon. Malay Literature 31(1), 69-97.

The Editors of Encyclopaedia Britannica. (2013). Historical Novel. Encylopaedia Britannica. Retrieved on 3 April 2018 from https://www.britannica.com/art/ historical-novel.

Received: 13 October 2018

Accepted: 11 March 2019 